\title{
Peran Guru PAI dalam Pengembangan Toleransi Peserta Didik melalui Budaya Sekolah di SMA N 8 Yogyakarta
}

\author{
Falasipatul Asifa \\ Universitas Islam Negeri Sunan Kalijaga Yogyakarta \\ Jl. Laksda Adisucipto, Papringan, Caturtunggal, Kec. Depok, Kabupaten Sleman, \\ Daerah Istimewa Yogyakarta 55281 \\ Email : falasifa.uinsuka@gmail.com
}

\begin{abstract}
In fact that the rapid development of science and technology has eroded the values of tolerance on the students shown by no mutual respect and respect for differences. The role of Islamic Religion Education (PAI) teachers as the heir of moral values and religious teaching of Islam were also supported by school culture into away and expected to be able to develop student tolerance. This research was a qualitative research, with the background SMA N 8 Yogyakarta. Data collection was conducted by observation, interview, and documentation. The result shows that: First, the role of PAI teacher for development tolerance through religious culture in SMA $N 8$ Yogyakarta was a designer, a movers, an evaluator, and a motivator. Second, the supported factors were adequate facilities and infrastructure such as places of worship and library. Good relationship between principals, teachers and employees, parents and students, and a supportive order. As for the inhibiting factor was the negative impact of science and technology.
\end{abstract}

Keywords: PAI teacher, tolerance, school culture

\begin{abstract}
Abstrak
Fakta bahwa berkembang pesatnya Ilmu Pengetahuan dan Teknologi telah mengikis nilai-nilai toleransi pada pelajar yang ditunjukkan dengan tidak ada sikap saling menghargai dan menghomati perbedaan yang ada. Peran guru PAI sebagai pewaris nilai-nilai moral dan ajaran agamaislam ditunjang pula dengan budaya sekolah menjadi cara dan diharapkan akan mampu mengembangkan toleransi peserta didik.Penelitian ini merupakan jenis penelitian kualitatif dengan mengambil latar SMA N 8 Yogyakarta.Pengumpulan data dilakukan dengan mengadakan observasi, wawancara dan dokumentasi.Dari hasil penelitian menunjukkan bahwa; Peran guru PAI dalam pengembangan toleransi peserta didik di SMA $N 8$ Yogyakarta adalah sebagai perancang, penggerak, evaluator, dan motivator.Adapun faktor pendukung guru PAI dalam mengembangkan toleransi peserta didik melalui budaya sekolah diantaranya adanya sarana dan prasarana yang memadai, seperti tempat ibadah, perpustakaan, hubungan yang baik antara Kepala Sekolah, guru dan karyawan, peserta didik dan orang tua peserta didik, tata tertib yang mendukung. Adapun faktor penghambatnya adalah dampak negatif perkembangan Ilmu Pengetahuan dan Teknologi.
\end{abstract}

Kata Kunci: guru PAI, toleransi, budaya sekolah 


\section{PENDAHULUAN}

Dalam lingkungan sekolah sebagaimana halnya dengan lingkungan masyarakat, memiliki banyak keberagaman terutama berkenaan dengan kehidupan dan aktivitas peserta didik. Peserta didik pada suatu sekolah cenderung membawa atau sekurang-kurangnya banyak dipengaruhi oleh lingkungan keluarga dengan berbagai bentuk kebiasaan-kebiasaannya serta masyarakat dengan berbagai latar belakang budayanya, dan sudah barang tentu dipengaruhi pula oleh nilai-nilai agama yang mereka anut. Kesemuanya ini akan tercermin dalam bentuk dan perilaku sehari-hari di sekolah. Oleh sebab itu dikalangan peserta didik juga penting dikembangkan nilai-nilai toleransi, agar mereka dapat menghormati dan menerima perbedaanperbedaan orang lain, dapat menghargai kebebasan-kebebasan fundamental peserta didik lainnya, tanpa perendahan diri, apalagi menghilangkan hak-hak individu dirinya. ${ }^{1}$

Hal tersebut di atas menunjukkan bahwa sekolah bertujuan untuk memersatukan segala aliran dan pandangan hidup yang dianut oleh peserta didik agar mampu hidup berdampingan dengan rukun dan damai sebagaimana semboyan bangsa Indonesia yang berbunyi "Bhineka Tunggal Ika". Namun seringkali titik temu perbedaan menjadi potensi konflik, khususnya pada kalangan pelajar.

Namun titik temu perbedaan seringkali menjadi pemicu konflik. Yogyakarta yang disebut sebagai City of Tolerance pada diskusi yang dihelat oleh CRCS melalui program Sekolah Pengelola Keragaman (SPK) dan Aliansi Nasional Bhineka Tunggal Ika (ANBTI) sedang dirundung banyak problema dalam hal toleransi. Terbukti sebagaimana yang disebutkan oleh Agnes Dwi Rusjiati pembicara dari ANBTI, kasus intoleransi seperti penyerangan dan pembubaran diskusi, perusakan situs makam, penyerangan terhadap doa Rosario, intimidasi terhadap kelompok tertentu seperti Syiah dan

${ }^{1}$ Busri Endang, Mengembangkan Toleransi dan Kebersamaan di Kalangan Peserta didik, Jurnal Visi Ilmu Pendidikan Vol.2, No. 2, 2011,hlm. 5.
LGBT, penghentian ibadah di gereja, serta usaha penutupan rumah ibadah kerap terjadi di kota yang dijuluki kota budaya ini. ${ }^{2}$

Dalam beberapa kasus juga dapat dijumpai maraknya perkelahian pelajar, kenakalan, kriminalitas. Kemarahan yang meledak menjadi tawuran pelajar, seringkali berawal dari suatu ketidaksengajaan yang sepele. Banyak pula pertarungan hanya karena solidaritas semu. Tetapi akibat dari ketidakmatangan emosi dan ketidakmampuan mengendalikan kemarahan tersebut berakibat fatal bagi masa depan anakanak bangsa. ${ }^{3}$

Disadari atau tidak disadari pengikisan toleransi pada pelajar merupakan akibat dari perubahan-perubahan yang terjadi pada berbagai aspek kehidupan sebagai dampak kemajuan Ilmu Pengetahuan dan Teknologi yang seringkali gegabah dinilai sebagai sesuatu yang lebih baik. Dampak yang lebih serius adalah pengkotak-kotakan kepentingan dalam bentuk berkembangnya individualisme, kepentingan kelompok yang dominan, kepentingan daerah, kepentingan suku, agama dan berbagai kepentingan dalam sub-sub yang lebih kecil.

Salah satu aspek yang paling menonjol untuk diperhatikan mengapa konflik-konflik tersebut sering terjadi adalah kurang efektifnya pendidikan agama di sekolah. Muhtar Bukhori dalam Muhaimin menilai kegagalan pendidikan agama disebabkan praktik pendidikannya hanya memperhatikan aspek kognitif semata daripada pertumbuhan kesadaran nilai-nilai (agama), dan mengabaikan pembinaan aspek afektif dan konatif-volatif, yakni kemauan dan tekad untuk mengamalkan nilai-nilai ajaran agama. Atau dalam praktik pendidikan agama berubah menjadi pengajaran agama, sehingga tidak mampu membentuk pribadi-pribadi bermoral. ${ }^{4}$

\footnotetext{
${ }^{2}$ Asep A. S, Intoleransi di Kota Toleran Yogyakarta, Yogyakarta: CRCS UGM, Januari 2016

${ }^{3}$ Imron Rosyidi, Pendidikan Berparadigma Inklusif: Upaya Memadukan Pengokohan Akidah dengan Pengembangan Sikap Toleransi dan Kerukunan, (Malang: UIN Malang press, 2009), hlm. 11.

${ }^{4}$ Muhaimin, Pengembangan Kurikulum Pendidikan Agama Islam di Sekolah, Madrasah, dan Perguruan
} 
Berdasarkan beberapa pertimbangan di atas, maka diperlukan keinginan yang kuat bagi setiap pendidik terutama guru PAI sebagai pewaris nilai-nilai moral dan ajaran agama Islam untuk secara terus-menerus berupaya mengembangkan toleransi ini kepada peserta didik, sehingga mereka mendapatkan latihanlatihan dan pengalaman yang bermakna terkait dengan aspek-aspek tersebut. Selanjutnya dapat dibawa dan dikembangkan dalam lingkungan masyarakat yang lebih majemuk. Hal ini sangat erat kaitannya dengan fungsi sekolah yang tanggungjawab utamanya adalah membantu peserta didik mengembangkan kemampuankemampuannya, sekaligus mempersiapkan mereka agar mampu beradaptasi, bersosialisasi bahkan lebih dari itu yaitu menjadi pelopor perubahan kebudayaan. ${ }^{5}$

Usaha guru PAI dalam mengembangkan toleransi kepada para peserta didik tentu tidak dapat berjalan baik apabila tidak diringi dengan budaya sekolah yang mendukung pengembangan toleransi tersebut. Pengembangan toleransi peserta didik juga tidak dapat dilepaskan dari budaya sekolah.

Terkait dengan penjelasan SMA N 8 Yogyakarta dengan letaknya yang berada di kota memungkinkan peserta didik memiliki kesempatan lebih banyak untuk berinteraksi dengan orang yang lebih heterogen dibandingkan dengan di desa yang cenderung homogen. SMA N 8 Yogyakarta memilikibasic pendidikan umum dan lingkungan sekolah yang plural. Sebagai upaya serius SMA N 8 Yogyakarta memiliki salah satu misi untuk mendukung toleransi yang berbunyi "Menciptakan budaya damai dan anti kekerasan". ${ }^{6}$ Selain itu, SMA N 8 Yogyakarta juga memiliki rasa kekeluargaan yang sangat erat.SMA N 8 Yogyakarta yang tampak majemuk dan memiliki rasa

Tinggi, (Jakarta: Rajawali Pers, 2012), hlm. 23.

${ }^{5}$ H.A.R. Tilaar, Pendidikan, Kebudayaan dan Masyarakat Madani Indonesia. Stratefi Reformasi Pendidikan Nasional, (Bandung: PT. Remaja Rosda Karya, 2000), hlm.76.

${ }^{6} \mathrm{http}: / /$ sman8yogya.sch.id/html/visimisi.html, diakses pada hari Kamis, 21 Mei 2015. kekeluargaan toleransi yang baik yang tumbuh di SMA N 8 Yogykarta.

Berangkat dari latar belakang tersebut,maka rumusan masalah dalam penelitian ini adalahbagaimana peran guru PAI dalam pengembangan toleransi melaluibudaya sekolah di SMA N 8 Yogyakarta dan apa saja faktor pendukung dan penghambat guru PAI dalam pengembangan toleransi melalui budaya sekolah di SMA N 8 Yogyakarta?

\section{METODE PENELITIAN}

Penelitian ini mengambil latar SMA N 8 Yogyakarta.Waktu penelitian dilaksanakan mulai November 2015-Januari 2016. Jenis penelitian ini adalah penelitian kualitatif. Penelitian kualitatif yaitu penelitian yang dimaksudkan untuk memahami fenomena tentang apa yang dialami oleh subjek penelitian, misalnya perilaku, motivasi, persepsi, tindakan, dan lain-lain, secara holistik, melalui pendiskripsian dalam bentuk kata-kata dan bahasa, pada suatu konteks khusus yang alamiah dan dengan memanfaatkan berbagai metode alamiah. $^{7}$

Sedangkan fokus pendekatannya menggunakan pendekatan psikologi pendidikan. Pendekatan ini digunakan dalam penelitian karena disiplin psikologi khusus mempelajari, meneliti, dan membahas seluruh tingkah laku manusia yang terlibat dalam proses pendidikan yang meliputi tingkah laku belajar, tingkah laku mengajar dan tingkah laku belajar mengajar. ${ }^{8}$

Data dalam penelitian ini didapatkan melalui beberapa cara yaitu: observasi proses kegiatan yang diadakan guru PAI yang menunjang pengembangan toleransi peserta didik di SMA N 8 Yogyakarta, guru PAI dan warga sekolah sebagai teladan dan keadaan toleransi peserta didik di SMA N 8 Yogyakarta dan wawancara kepala sekolah. Guru mata pelajaran Pendidikan Agama Islam SMA N

${ }^{7}$ Lexy J. Meleong, Metode Penelitian Kualitatif, (Bandung: PT Remaja Rosda Karya, 2005), hlm. 6.

${ }^{8}$ Muhibbin Syah, Psikologi Pendidikan dengan Pendekatan Baru, (Bandung: PT. Remaja Rosdakarya, 1997), hlm. 24. 
8 Yogyakarta untuk mengetahui bagaimana bentuk pengembangan toleransi peserta didik yang dilakukannya, wakil kepala kurikulum untuk mengetahui kegiatan yang dilaksanakan untuk menunjang toleransi peserta didik serta peserta didik untuk memperoleh data bagaimana bentuk toleransi peserta didik yang dilakukan di sekolah. Dokumentasi merupakan data yang diperoleh dari dokumen dapat berbentuk buku file dan arsip di kantor Tata Usaha SMA N 8 Yogyakarta.

Analisis data yang dilakukan dengan memberikan makna terhadap data yang berhasil dikumpulkan, dan dari makna itulah ditarik kesimpulan.Pemeriksaan keabsahan data dilakukan dengan mengadakan triangulasi. Triangulasi adalah teknik pemeriksaan keabsahan data yang memanfaatkan sesuatu yang lain di luar data itu untuk keperluan pengecekan atau sebagai pembanding terhadap data itu. Triangulasi dalam penelitian ini menggunakan triangulasi dengan sumber dan metode.

\section{PEMBAHASAN}

\section{Peran Guru PAI dalam Pengembangan Toleransi Peserta didik Melalui Budaya Sekolah}

SMA N 8 Yogyakarta berada dekat Balai Kota Yogyakarta tepatnya di J1. Sidobali No. 1 Muja-Muju Umbulharjo kota Yogyakarta. Berkenaan toleransi, SMA N 8 Yogyakarta memiliki salah satu misi yang berbunyi "Menciptakan budaya damai dan anti kekerasan".Berdasarkan hasil penelitian di SMA N 8 Yogyakarta dalam mengembangkan toleransi peserta didik, guru PAI berperan sebagai perancang, penggerak, evaluator dan motivator di sekolah.

\section{Sebagai Perancang}

Sebagai perancang artinya guru PAI berperan menyusun suatu kegiatan untuk mengembangkan toleransi peserta didik baik di dalam kelas maupun di luar kelas. Sebagai perancang di dalam kelas guru PAI menyusun RPP sebagai langkah awal sebelum memulai kegiatan pembelajaran. Dengan RPP guru dapat mendesain pembelajaran yang akan dilakukannya termasuk mendesain pembelajaran yang mendorong pengembangan toleransi peserta didik. Sebagai perancang di luar kelas guru PAI tidak secara langsung merancang kegiatan tersebut, namun melalui anggota forum SAI yang dibimbingnya dengan cara mengarahkan kegiatan yang akan diadakan forum SAI sejak awal dari susunan panitia sampai pada pelaksanaan dan evaluasi.

\section{Sebagai Penggerak}

Guru PAI sebagai penggerak artinya guru sebagai mobilisator yang mendorong dan menggerakkan sistem organisasi sekolah. Guru PAI menggerakkan sistem sekolah dalam bentuk kegiatan yang dapat mengembangan toleransi peserta didik sebagai berikut:

\section{Kegiatan Rutin}

Kegiatan rutin merupakan kegiatan yang dilaksanakan secara terus- menerus dan konsisten setiap saat oleh peserta didik. Diantara kegiatan rutin yang dapat mengembangkan toleransi peserta didik yaitu: Pertama, sebagai agen pembelajaran guru PAI mengembangkan toleransi peserta didik melalui kegiatan pembelajaran di kelas dengan beberapa metode pembelajaran. Diantara metode pembelajaran yang digunakan oleh guru PAI untuk mengembangkan toleransi peserta didik adalah diskusi dan tanya jawab. Menurutnya, dengan metode diskusi dan tanya jawab peserta didik akan terlatih untuk memecahkan masalah secara bersama dan menghargai perbedaan pendapat dengan teman lain. Hal ini merupakan modal penting bagi peserta didik untuk mempunyai sikap toleran terhadap perbedaan yang lebih besar di lingkungannya.

Kedua, bersalaman atau berjabat tangan antara peserta didik dengan guru. Bersalaman dilakukan setiap hari olehpeserta didiksebelum masukkedalamkelas. Melalui budaya bersalaman ini mampu mengembangkan toleransi peserta didik karena dengan bersalaman membimbing peserta didik untuk bersikap sopan santun 
sehingga menumbuhkan rasa kekeluargaan tanpa ada pembedaan dan menghilangkan prasangka di antara peserta didik terhadap perbedaan yang ada. Sehingga budaya ini dapat mendorong perdamaian sebagai pokok dari toleransi.Dengan budaya bersalaman berarti mendukung setiap persatuan dan kesatuan warga sekolah. Kesadaran diri akan sikap toleran juga semakin terbina mengingat pelaksanaan budaya ini berujung pada terciptanya hubungan yang baik antarpeserta didik.

Ketiga, tadarus. Tadarus adalah membaca al-Qur'an. Tadarus dilakukan sebelum memulai kegiatan pembelajaran secara bersama-sama secara terpusat yang dimulai dari pukul 07.00 WIB. Tadarus dilaksanakan oleh peserta didik yang beragama Islam, namun peserta didik yang non-islam tidak diistirahatkan, melainkan ditempatkan di ruang agama masing-masing dan melakukan kajian agama bersama guru agamanya masing-masing. Hal ini agar setiap peserta didik mendapatkan ajaran agamanya tanpa ada peminggiran terhadap pemeluk agama minoritas. Aktivitas ini memperlihatkan bagaimana setiap peserta didik dapat melaksanakan kegiatan agamanya dan menghormati pelaksanaan kegiatan agama yang lain.

Keempat, Pembinaan SAI (Sivita Aktivita Islamika) yaitu forum di bawah OSIS yang mengurusi kegiatan yang bersifat islami. Adapun beberapa kegiatan SAI yang dapat mengembangkan toleransi diantaranya:Baksos diadakan setiap satu tahun sekali sesuai situasi dan kondisi. Daerah yang biasa dijadikan tujuan bakti sosial adalah Gunung Kidul. Adapun barang-barang yang diberikan berupa sembako, buku dan pakaian yang merupakan hasil sumbangan dari semua peserta didik SMA N 8 Yogyakarta. Kegiatan baksos untuk memupuk rasa adil peserta didik terhadap hak-hak manusia karena dengan kegiatan baksos peserta didik diajak turut empati terhadap keadaan yang dialami oleh orang lain. Dengan hal itu peserta didik akan mengetahui bahwa nikmat dan harta yang mereka miliki sesungguhnya terdapat hak orang yang membutuhkan yang harus diberikan. Bisal (Baitul Ilmi Salsabila) Divotion. Bisal
Divotion merupakan singkatan dari dua nama mushola yang ada di SMAN 8 Yogyakarta yaitu Mushola ikhwan yang dinamakan Baitul Ilmi dan mushola akhwat yang dinamakan Salsabila. Kegiatan yang ada dalam Bisal Divotion berupa pelatihan. Kagiatan ini sangat mendukung untuk mengembangkan toleransi peserta didik karena esensi dari pelatihan dalam kegiatan ini mengajak peserta didik untuk bersikap sesuai ajaran Islam baik dalam kehidupan sehari-hari maupun sebagai pemimpin seperti Rasulullah. Materi pelatihan tentang etika yang mengajarkan peserta didik untuk bersikap sopan santun, bertutur kata yang etis sehingga menghindari perbuatan saling menyakiti dan tercipta hidup berdampingan yang rukun dan damai. Selain tentang etika, juga diajarkan tentang confidence yang menjelaskan bahwa Islam mengajarkan peserta didik untuk memiliki rasa percaya diri sehingga berani tampil di depan dan mengungkapkan pendapat dengan tetap menghargai pendapat orang lain.

Selanjutnya pengajian Jum'at. Kegiatan pengajian ini dilaksanakan setiap hari Jum'at setelah shalat Jum'at di Masjid. Pengisi ceramah sebagai mentor adalah dari alumni SMA N 8 Yogyakarta. Pengajian Jum'at penting untuk menambah wawasan agama Islam peserta didik sebagai agama rohmatan lil 'alamin yang mencintai perdamaian. Sehingga dampaknya peserta didik mampu bersikap toleran baik dalam lingkup intern agama Islam maupun lingkup ekstern antarumat beragama. Ada juga sepeda dakwah yaitu kegiatan untuk peserta didik kelas X, bersepeda dari sekolah ke tempat tujuan yang kurang lebih jaraknya $13 \mathrm{~km}$. Sesuai dengan namanya, kegiatan ini dilakukan dengan bersepeda sambil berdakwah dan berukhuwah. Melalui kegiatan sepeda dakwah peserta didik diajarkan peduli terhadap lingkungan karena dalam perjalanan peserta didik memungut sampah yang ditemukan berceceran dan menyapa setiap orang yang ditemui selama perjalanan. Selain itu, kegiatan ini untuk mempererat tali persaudaraan dan keakraban diantara peserta didik baik yang Islam maupun non-Islam dan mengenal lingkungan selama perjalanan mengunakan 
sepeda. Hal ini penting untuk mengembangkan toleransi peserta didik dengan lebih mengenal sesama dan lingkungan sekitar.

Pembinaan yang terakhir yaitu kegiatan lomba.Lomba di SMAN 8 Yogyakarta biasanya diadakan dalam rangka memperingati PHBN maupun PHBI seperti lomba memasak daging pada saat Hari Raya Idul Adha.Dengan, mengadakan lomba yang mengharuskan peserta didik saling menghargai dan menerima atas tugas yang telah dibagikan tanpa rasa paling bisa dan pintar sendiri sehingga tidak ada dominasi peserta didik yang mengikuti lomba. Selain itu, dengan adanya lomba-lomba tersebut dapat menumbuhkan jiwa falsafah pancasila peserta didik sebagai bangsa Indonesia sebagai salah satu indikator toleransi.

\section{Kegiatan Spontan}

Kegiatan spontan merupakan kegiatan spontan, saat itu juga waktu terjadinya keadaan. Beberapa kegiatan spontanyang dapat mengembangkan toleransipeserta didik diantaranya: Pertama, Infak lelayu untuk melatihpeserta didik agar dapat sadar dan peduli terhadap hak sesama manusia untuk saling menolong karena itu juga merupakan kewajiban manusia apabila ada orang lain yang tertimpa musibah.Dengan rasa peduli sehingga tumbuh empati pada diri peserta didik yang dapat meningkatkan sikap toleran

Kedua, menjenguk teman sakit.Bentuk toleransi dari kegiatan tersebut adalah memenuhi hak orang lain untuk dijenguk dan didoakan apabila sedang sakit.Dengan menjenguk teman yang sakit atau terkena musibah melatih peserta didik lebih peduli terhadap sesama, empati yang besar terhadap sesama manusia, kepekaan akan lingkungan sekitar, mengasihi dan menyayangi orang lain, dan mau merasakan apa yang dirasakan oleh orang lain. Apabila peserta didik dapat merasakan itu semua, maka toleransi menjadi hal yang penting bagi mereka.

\section{Pengondisian}

Pengondisian sebagai upaya untuk mengondisikan suasana sekolah dengan nilai- nilai dan perilaku yang toleransi. Bentuk pengondisian yang dilakukan guru PAI berupa menciptakan iklim pembelajaran yang toleransi dan memberikan kesempatan kepada peserta didik untuk melaksanakan ibadahnya mendorong peserta didik agar adil terhadap hak dan kewajibannya.

Selain iklim pembelajaran juga penting untuk menciptakan iklim persaudaraan yang menunjukkan rasa saling menyayangi, menghormati, dan menghargai pada setiap individu dalam hubungannya di lingkungan sekolah.Sehingga hubungan antara Kepala Sekolah, guru dan peserta didik menjadi hubungan baik yang mampu menumbuhkan sikap kepedulian sebagai sikap pokok dalam toleransi.

\section{Sebagai Evaluator}

Sebagai evaluator guru melakukan penilaian atau evaluasi terhadap kegiatan yang telah dilaksanakan dan penilaian terhadap prestasi serta sikap peserta didik. Ketika pembelajaran guru menilai prestasi peserta didik melalui indikator yang telah ditentukan. Evaluasi sikap toleran peserta didik, guru PAI mengamati lewat pembicaraan dan sikap yang ditunjukkan baik ketika di kelas maupun di luar kelas. Apabila ada peserta didik yang dianggap masih kurang memiliki toleransi, guru akan melakukan pendekatan perorang dan pendekatan kelompok sesuai dengan situasi dan kondisi.

\section{Sebagai Motivator}

Sebagai pendidik, guru juga harus mampu memberikan motivasi kepada peserta didik.Motivasi adalah pemberian dorongan, semangat dan dukungan. Salah satu bentuk motivasi yang diberikan guru PAI untuk mengembangkan toleransi peserta didik adalah dengan keteladanan dan ajakan. Keteladanan merupakan contoh nyata yang dapat memotivasi peserta didik untuk bersikap sesuai dengan keadaan yang mereka lihat dengan apa adanya. Bentuk keteladanan yang dilakukan guru PAI yaitu menghargai pendapat peserta didik ketika 
di kelas, memberikan toleransi kepada peserta didik yang tidak mengenakan jilbab, menaati tata tertib sebagaimana peserta didik, mengingatkan peserta didik yang bersikap kurang baik dan melanggar tata tertib, melaksanakan shalat jamaah dan shalat Dhuha.

\section{Faktor Pendukung dan Penghambat Guru PAI dalam Mengembangkan Toleransi Peserta didik SMA N 8 Yogyakarta Faktor Pendukung}

Faktor pendukung guru PAI dalam pengembangan toleransi peserta didik melalui budaya sekolah yaitu: Sarana dan prasarana yang memadai seperti tempat ibadah yaitu masjid dan ruang ibadah agama non Islam yang menunjang toleransi antarumat bergama yang tampak dari sikap saling menghormati ketika agama yang lain sedang melakukan ibadah. Hal ini sebagai pemenuhan atas hak setiap agama untuk melakukan ibadahnya dan sekolah memberikan fasilitas untuk pelaksanaan ibadah.

Perpustakaan sebagai salah satu sumber belajar bagi peserta didik memiliki posisi yang strategis untuk menggali pengetahuan tidak terkecuali tentang toleransi.Perpustakaan memiliki koleksi buku-buku tentang toleransi yang dapat dibaca oleh peserta didik untuk menambah wawasan keragaman yang ada dan menumbuhkan sikap untuk menghargai perbedaan yang ada.

Selain sarana dan prasarana yang dapat mendukung pengembangan toleransi melalui budaya sekolah yaitu tata tertib.Hal ini sangat penting untuk membentuk karakter peserta didik karena tata tertib merupakan panduan peserta didik dalam bersikap dan berperilaku di sekolah. Beberapa tata tertib yang menunjang pengembangan toleransi peserta didik seperti budaya 5S (Senyum, Salam, Sapa, Sopan, Santun) setiap pagi ketika berangkat sekolah di depan gerbang dengan guru piket dan setiap waktu ketika di lingkungan sekolah. Tadarus pagi bagi peserta didikmuslim dan kajian agama bagi peserta didik non islam.

Hubungan yang baik antara kepala sekolah, guru dan karyawan, peserta didik, dan orang tua peserta didik juga penting sebagai contoh toleransi bagi peserta didik. Kerjasama yang baik antara kepala sekolah, guru dan karyawan, peserta didik, dan orang tua peserta didik sangat mendukung dalam mencapai suatu tujuan yang di ingin dicapai. Dalam pengembangan toleransi peserta didik melalui budaya sekolah pada dasarnya semua warga sekolah sangat berperan penting dalam hal tersebut. Sikap yang ditunjukkan oleh warga sekolah mendorong peserta didik untuk melakukan hal yang sama yang dilakukan oleh guru sebagai teladan.

Organisasi di luar sekolah juga mendukung untuk meningkatkan kompetensi guru dalam mengembangakan toleransi peserta didik. yaitu guru selain aktif di sekolah juga aktif mengikuti organisasi di luar sekolah. Hal ini sangat baik untuk menerapkan pengalaman yang didapatkan dari organisasi di luar sekolah untuk mengembangkan toleransi peserta didik di sekolah.

\section{Faktor Penghambat}

Hal yang perlu mendapat perhatian serius karena aksesnya yang mudah dan begitu berpengaruh yaitu perkembangan IPTEK. Dengan meluasnya informasi yang mudah diakses melalui internet darimana dan kapan saja ini membuat peserta didik menjadi generasi instan dan kabur akan nilai budaya sendiri dengan budaya barat apabila tidak diimbangi dengan kontrol yang baik. Berbagai informasi dan sikap individual, anarkis, dan stereotip yang peserta didik dapatkan dari berbadai media baik internet, TV, dan lain sebagainya tidak bisa dengan mudah guru kontrol.

\section{KESIMPULAN}

Pada dasarnya peran guru PAI dalam pengembangan toleransi peserta didik melalui budaya sekolah di SMA N 8 Yogyakarta sebagai perancang, penggerak, evaluator dan motivator. Hal ini sesuai dengan peran guru menurut Mujtahid yang dipadukan dengan pendapat Zuhairini yang lebih spesifik mengemukakan peran guru PAI yaitu mengajarkan ilmu 
pengetahuan agama islam, menanamkan keimanan dalam jiwa anak, mendidik anak agar taat menjalankan agama, dan mendidik anak agar berbudi pekerti luhur yang mulia.

Di dalam guru PAI mengembangkan toleransi peserta didik melalui budaya sekolah di SMA N 8 Yogyakarta terdapat dua faktor, yaitu faktor pendukung dan faktor penghambat. Faktor pendukung guru PAI dalam mengembangkan toleransi peserta didik melalui budaya sekolah diantaranya keadaan sarana dan prasarana yang mendukung seperti tempat ibadah, dan perpustakaan, adanya tata tertib yang mendukung pengembangan toleransi peserta didik, hubungan yang baik antara pihak sekolah dan orang tua peserta didik, serta organisasi di luar sekolah yang diikuti oleh guru PAI. Sedangkan faktor penghambat pengembangan toleransi peserta didik melalui budaya sekolah di SMA N 8 Yogyakarta adalah perkembangan IPTEK yang membawa sedikit banyak dampak negative yang tidak dapat guru control.

\section{DAFTAR PUSTAKA}

Endang,Busri.2011.Mengembangkan Toleransi dan Kebersamaan di Kalangan Peserta didik, Jurnal Visi Ilmu Pendidikan Vol.2, No. 2.

http://sman8yogya.sch.id/html/visimisi.html, diakses pada hari Kamis, 21 Mei 2015.

Meleong,Lexy J. 2005. Metode Penelitian Kualitatif,Bandung: PT Remaja Rosda Karya.

Muhaimin. 2012. Pengembangan Kurikulum Pendidikan Agama Islam di Sekolah, Madrasah, dan Perguruan Tinggi, Jakarta: Rajawali Pers.

Rosyidi, Imron. 2009. Pendidikan Berparadigma Inklusif: Upaya Memadukan Pengokohan Akidah dengan Pengembangan Sikap Toleransi dan Kerukunan, Malang: UIN Malang press.

$\mathrm{S}$, Asep A. Intoleransi di Kota Toleran Yogyakarta, Yogyakarta: CRCS UGM, Januari 2016

Syah, Muhibbin.1997. Psikologi Pendidikan dengan Pendekatan Baru, Bandung: PT. Remaja Rosdakarya.

Tilaar,H.A.R. 2000.Pendidikan, Kebudayaan dan Masyarakat Madani Indonesia. Stratefi Reformasi Pendidikan Nasional, Bandung: PT. Remaja Rosda Karya. 